\title{
Football and psychosis ${ }^{\star}$
}

\author{
Franck Nolot, ${ }^{1}$ Christian Védie, ${ }^{1}$ translated by Alistair Stewart ${ }^{2}$
}

The Psychiatrist (2012), 36, 307-309, doi: 10.1192/pb.bp.112.038570

${ }^{1}$ Centre Hospitalier Valvert, Marseille, France; ${ }^{2}$ Royal Oldham Hospital, Oldham, UK

Correspondence to Alistair Stewart (alistair.stewart@nhs.net)

First received 13 Jan 2012, accepted 16 Jan 2012
Summary After 25 years of promoting football in psychiatric hospitals, the authors highlight the potential benefits of sport and physical activity in treating people diagnosed with psychosis. A number of clinical cases are used to illustrate the benefits to individual people as well as to the collective and the institution.

Declaration of interest None.

\section{History of football in psychiatric institutions}

In the 1930s, Enrique Pichon-Rivière arrived at the Asilode-Torres in Argentina. About 3500 patients, diagnosed in line with the classification of the time as 'oligophrenic', were more or less left to fester in an institution which demeaned and excluded them. As he put it, 'it was absolutely essential to do something new, because the place was a complete

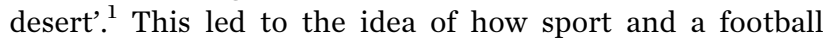
team can function as a form of dynamic group therapy.

In France the movement to bring sport into psychiatry was mixed up with several other debates - about institutionalisation, residential therapy, social inclusion and even the ethics of sport. Daumezon, medical director at the hospital of Fleury-les-Aubrais, first used the term 'institutional therapy', defining it as the therapeutic use of social life as it is actually being lived. ${ }^{2}$ He and Sivadon from Ville-Evrard organised the first inter-hospital football and basketball matches in 1948.

As the old asylums started to empty, the possible uses of sport in psychiatry became clearer:

- a medical benefit in the form of basic personal and physical hygiene and fitness

- an educational function

- an effect on the institution.

Hospitals in Rennes and then Le Mans joined these meetings in 1950. The football tournament organised at Le Mans in 1956, with eight hospitals taking part, was the first event in an uninterrupted line of meetings which has continued right up until the present day. The year 1962 saw the birth of the union of sports associations of French psychiatric hospitals, bringing together 27 institutions. In 1997 it was re-launched as 'Sport on the Brain' ('Sport en tête', www.sport-en-tete.fr), by then involving 60 establishments. Between 1982 and 2008 we have been able to track

*This is an abridged version. First published in French: F. Nolot, C. Védie: Football et psychose. Annales médico-psychologiques, revue psychiatrique, Volume 166, Issue 10, December 2008, Pages 870-874. Copyright (C) 2008 Published by Elsevier Masson SAS. All rights reserved. www.sciencedirect.com/science/journal/00034487 the development of the use of football as a central therapeutic activity in a psychiatric clinic in Marseilles, the Centre Hospitalier Valvert. This has included running nearly 1300 training sessions, around 60 tournaments and 100 or so friendly matches.

At the beginning of the 1980s we were still using the rules established by the Fédération Internationale de Football Association (FIFA) and had not yet effectively adapted them to our own needs. The competitive system created a number of problems. Marie-Christine Lanfranchi noted in 1995: '. . . activities organised under the heading of a training session or a match are of limited use. Effectively they ensure that only people who have been involved in sport before will get something out of it. To a lot of the nurses, the thing which seems most important is winning the match'. 3

In a knockout situation, losing a match can mean the end of the season. This encourages a kind of overdramatic interpretation along the lines of: 'We have got to win', i.e. 'otherwise I am lost'. Some games in inter-hospital matches have been marred by incidents just as bad as those seen in many amateur and professional competitions: arguments, suspicion, verbal abuse, attacks on the referee and dangerous play. Growing criticism of these tendencies led to a rethink. In 1992, the term 'French championship' was abandoned in favour of that of 'national meetings'. Instead of teams of 11 players, seven-a-side competitions were introduced. The proportion of nurses in the teams changed from $5 / 11$ to $2 / 7$. Most often tournaments were organised at a local or regional level. At the national level there is an annual tournament. Problems of bad sportsmanship have gradually almost disappeared, and at least at a local level teams often referee themselves.

Without realising it we have come back to an approach which is 170 years old: the founders of the game of football took the view that a foul could not be deliberate, and refereeing was in the hands of team captains. A referee was not considered necessary until 1847. Different arrangements have arisen to allow the best way of running games and tournaments based on the players' level of skill. We have arrived at a style of playing where goals are frequent and so 
the matter of scoring or conceding a goal becomes less overdramatised.

\section{The therapeutic use of football in the treatment of psychosis}

In France in 1945, Sivadon suggested that physical activity has an important place in the care of people with chronic mental illness. ${ }^{4}$ It allows the setting of precise objectives such as the achievement of personal autonomy, improvement in interpersonal relationships, the growth of awareness and the strengthening of a sense of self. By their nature, collective sports, among them football, act as a kind of communication network.

By means of three brief clinical vignettes, we will try to clarify some aspects of the relationship between football and psychosis.

\section{Clinical cases}

\section{Case vignette 1: M.B. or body memory}

'M.B., age 40 and diagnosed with schizophrenia, was referred to us as a day hospital patient during the month of July 1998, at the peak of national football fever during the World Cup in France. Right from the beginning M.B. fitted the stereotype of a long-stay ward patient; his wary, closed manner, his fleeting eye contact, his responses off the point, and his permanent tiredness, all represented obstacles to the efforts and suggestions of nurses to break this cycle. That is, until the day when he grumpily agreed to be a spectator at a sports session. And that day it was football.

A powerful shot missed the goal and the ball flew off the pitch straight at him. Much to everyone's surprise he brought it under control with two touches - left foot, right foot, all the while sitting in a chair on the touchline. When he did the same with a second ball, this time fired at him deliberately, there could be no more doubts. 'That boy's got skill', said a patient. M.B. was quickly involved in training sessions, despite continuing to wear between five and eight layers of clothes. Now, his attempts to copy other players are often clumsy, he does not move very much and covers just a small part of the field without leaving it once during the match; sometimes you have to call him before passing him the ball. He finds it difficult to deal with balls in the air, but his ground level play is very skilful. His shots on goal are very accurate, whatever the angle, with results which regularly surprise both his opponents and his teammates.'

Case vignette 2: M.U. or the selfless defender

'M.U. is 28 years old and has schizophrenia. For the past 8 years he has alternated between stays in hospital and periods of rest at his mother's home. He had become very withdrawn into himself so that the nursing staff were unsuccessful in trying to engage him and eventually had to insist that he came to the gym for a game of football. His technical skills were basic, but he was physically fit. On the pitch he has little feel for offensive play. His shots on goal are wild and mistimed and he has little awareness of his position on the field or the development of the game. However, in a defensive position he performs as well as anyone could wish. He never deserts his position. He is reliable and always gives his best; even when tired he will never ask to be substituted, but when this happens he accepts it without complaint. He is a real team player, always helping out his fellow defenders when they are in difficulty, without ever criticising them.'

\section{Case vignette 3: M.L. or the dark horse}

'M.L. is 32 years old and has paranoid schizophrenia. He had his first breakdown as a teenager. When we first met him he was 22 years old. He was beginning to put on a great deal of weight, was heavily addicted to cigarettes and he seemed generally very slowed down. All this completely obscured his sporting past. It turned out that he had been a club player between the ages of 5 and 16 where he was often singled out for praise.

He would never play for us unless he was asked, but in fact, given his skills, he was picked much more frequently by the patients than by the nursing staff. Some patients would refuse to play in a match if he was not there, saying 'we'll never win without him'. He was a very effective player. He would play in any position including that of goalkeeper. He showed exceptional skills in the development of play and had boundless creativity. Because of what he could do with the ball even in the most difficult situations, he became known as the 'artist' of the team. Sometimes other players have merited this title, but they were usually selfish players who did not bring much to the team.

With M.L. it is different. The artistry of his play never comes at the expense of effective passes, shots or tackles. He makes very few mistakes and never questions the decisions of the referee. During every match or training session, he remains completely silent. He continues to put on weight and the only time he stops smoking is when he has run out of cigarettes.'

\section{Football and psychosis}

Nearly all disputes during matches are started by players who have neurotic problems. Their constant refrain is: 'we won because we were the best; we lost because of the referee or because of bad luck'. Players who have problems of a psychotic type seem to find it much easier to accept the important part played by chance in deciding the results of many matches. As a consequence, they also find it easier to live with the mistakes of the referee or of their teammates. When they score a goal they do not indulge in histrionics, even if they are clearly very satisfied with their success.

People do identify with famous players, but not often by imitating their behaviour as seen on television. Usually they will adopt the surname or first name of a famous player, often in an ironic way. Their behaviour is generally marked by its appropriateness, economy and discretion. Although they will rarely criticise their teammates even when they are responsible for their errors, they are all very eager for praise.

\section{The therapeutic benefits of football}

During a game of football, the usual rules which govern the behaviour of nurses and patients no longer hold. Some patients who are considered difficult are very keen on football and it changes their behaviour, so that on the day of a game they are more open and calmer. Patients who come along as spectators also benefit as they are carried away by the flow of the game, the noise and the excitement which contrasts with the usual quiet of the hospital. Messrs B, L and $U$ are men of few words. Most interviews with them are not very fruitful. On the other hand, their way of expressing themselves through football is very rich. They pass, they receive, they exchange the ball, they block. They finish. These interactions with their nurse teammates become something permanent. A new language is freed up, the language of the body.

They then acquire a new status, among other things the status of someone who the team cannot do without. Their performance on the pitch makes people look at them and sometimes this may be the first time they have become 
visible to those around them. If we had to pinpoint the origin of communication between these three people and the nurses looking after them, we could do worse than paraphrase a famous book, 'in the beginning was the ball'. In Marseille, we do not like football, we like Olympique Marseille or we like 'footie' (or both).

There is not much connection between the mixed hospital teams made up of patients and nurses with other football networks where they live, even though everyone has a keen interest in the ups and downs of the big local club. The well-known hostilities associated with professional football are unknown here, Valvert $v$. Ville-Evrard is not a reflection of Olympique Marseille $v$. Paris St Germain. Most teams anyway take their names from the hospital from which they come, rather than from their town and the local region.

Messrs B, U and L offer a fairly representative example of how some of the patients with schizophrenia we have met in the beautiful game during these past 25 years are able to overcome their problems.

\section{Football and society}

\section{Football, violence and injustice}

The violent nature of football or the violence mixed in with football is well known, as are verbal aggression and offensive gestures from spectators, between players and against the referee, and between managers. The list goes on. During 75 inter-hospital tournaments which we have attended, there have been two serious incidents in a match, once when a referee was attacked and once when a player was seriously injured by a foul. On both occasions the patients responsible were removed.

There are just as many refereeing errors, real or imagined, as in football elsewhere. Players react to these in a lively and sometimes passionate way, but only ever using words. There are many examples of fair play. Some patients with schizophrenia, even though they are intentionally involved and active in the match, seem to be emotionally indifferent to whether they win or lose, to unfairness, to stress or to attempts to provoke them.

Football is a sport where scores tend to be low, for example in the European Championships the average number of goals per match varies between 2.2 and 2.7. This means a goal about once every $40 \mathrm{~min}$, very different from what happens in basketball or handball. The thing which marks football out from other team games and what underlies its success is that the old cliché 'let the best team win' is just a vain and pious wish. Unlike other sports, in football even the best team on the field is never sure of victory because that will often depend on one little goal which can be blocked by a goalpost, someone's leg or a decision from the referee.

\section{Football and refereeing}

Every therapy depends a great deal on setting a framework. This framework is chosen, unlike regulations which are imposed. In this sense the 17 laws of football, which are very difficult to apply and very frequently disputed, are more regulation than framework. This means that nurses and patients have to free themselves a bit from the rules to achieve a reasonable common ground and keep things therapeutic. This in turn means that we have to question the role of referees in modern football. The rules of football allow an enormous scope for interpretation. Refereeing has become an art. Even video recordings are not the perfect reflection of reality. Forty years after the famous World Cup final between England and West Germany, even after watching the same footage hundreds of times, nobody knows for sure whether in the goal which gave England the decisive advantage the ball had actually crossed the line. As for the offside rule, given the speed of the modern game and the length of passes, it is sometimes beyond the physical capacity of the human eye to decide whether someone is offside. This means that it will be only when severe penalties for unfair play are applied, including sometimes after the match, that things will improve and the human factor will again come to the fore. Even though we accept that it is necessary and unavoidable for video evidence to underpin refereeing, let us hope that the cure will not be worse than the disease.

\section{Conclusion}

'Everything we accomplish in life we do despite handicaps of which we are not aware'- so said Lawrence Durrell in Balthazar. ${ }^{5}$ More important than the therapeutic benefits of football is what illness or handicap can bring to enrich wider society. Most patients with psychosis who have taken part in our games have enabled us, through their behaviour, to see what the first footballers considered important - fair play, self-referring and so on. If this attitude spread, football could once again become one of the activities chosen by people who are really seeking to be themselves. In a team game, some people help the team and others are helped by the team; from this point of view Messrs B, U and L are exemplary, even ideal, teammates. When he was asked 'What do you think of the way you played in the last competition?', M.B. replied 'Football is what brings us to life'.

\section{About the authors}

Franck Nolot, occupational therapist, Christian Védie, clinical director Centre Hospitalier Valvert, Marseille, France; Alistair Stewart, consultant psychiatrist, Royal Oldham Hospital, Oldham, UK.

\section{References}

1 Mahieu E. L'Argentine, entre la psychanalyse et le football: le rugby [Argentina, between psychoanalysis and football: rubgy]. Cercle d'études psychiatriques Henri Ey de Paris, 2004 (http:// eduardo.mahieu.free.fr/2004/rugby.htm)

2 Daumezon G, Koechlin P (1952). La psychotherapie institutionelle francaise contemporaine [Contemporary French institutional psychotherapy]. Reprinted (2009) in Psychoanalytische Perspektieven 2009; 27: 215-34. Available online at http://www. psychoanalytischeperspectieven.be/on-line\%20papers/papers/ 2009\%20(1-2)\%20Daumézon.pdf.

3 Lanfranchi MC, Les activités physiques et eportives dans le projet de soin infirmier: moteur de l'équipe soignante [Sport and physical activity as a driving force in patient care]. Éditions ENSP, 1995.

4 Sivadon P, Gantheret F. L rééducation corporelle des fonctions mentales [Rehabilitation of mental functioning by means of physical activity]. ESF, 1965.

5 Durrell L. Balthazar. Faber and Faber, 1958. 